\title{
EXAMINING THE INTERNATIONAL LAW RIGHT OF SELF-DEFENCE: THE CASE OF RUSSIA AND GEORGIA; ISRAEL AND GAZA*
}

\author{
FT Abioye \\ LLB LLM \\ Senior Lecturer in Department of Jurisprudence \\ University of South Africa (UNISA)
}

SUMMARY

Article 2(4) of the UN Charter establishes the doctrine of the prohibition of the use of force amongst member states of the UN. Article 51 lays down exceptions to this rule in terms of the fact that there can be an individual and/or collective use of force in self-defence in the case of an armed attack. This individual or collective use of force is permitted to continue until such a time as the Security Council takes such actions as are necessary for the maintenance of international peace and security. The International Court of Justice (ICJ) has further confirmed this prohibition of the use of force in the Nicaragua case, Congo v Uganda and Oil Platforms cases. This area of international law has seen a lot of discussions and developments over the years. The purpose of this article is to examine the efficacy of the use of force between Russia and Georgia; and Israel and Gaza in 2008. It would be examined if these armed attacks are justifiable by the doctrine of self-defence and the recent developments in the field in international law, or if they in fact constitute a breach of the international law prohibition on the use of force.

\section{$1 \quad$ INTRODUCTION}

\section{Russia and Georgia}

On the night of 1 August 2008 Georgian forces made quick forays into Tskhinvali, in South Ossetia. South Ossetia is a "semi-autonomous" region in Georgia which had repeatedly expressed its desire to be independent from Georgia. It had as far back as 1992 announced its independence and declared itself an autonomous state, but has to date failed to get the necessary recognition of its independence from the international community, and thus it is still considered as part of Georgia. ${ }^{1}$ On the fateful night gunfire

Paper presented at the Southern African Law Teachers Conference, Pietermaritzburg, July 12-16 2009

Barouski "Russia and Georgia: International Law Norms and Considerations" http://getoff this.blogspot.com/2008/10/russia-and-georgia-international-law.html (accessed 2009-0502). 
was exchanged with the South Ossetian militia for a couple of hours, after which Georgia withdrew its forces. This was repeated over the next couple of days, and was then accompanied by the deployment of Georgian forces to the South Ossetia border for a more definitive strike. This resulted in a build up of tanks and heavy weapons on the South Ossetia border with Georgia. $^{2}$

The tension generated by this situation led to intermittent battles between the Georgian army and the South Ossetian militia, and eventually on the night of 8 August, the Georgian army moved in on South Ossetia and attacked it with mortar and artillery shells and rocket launches. ${ }^{3}$ The area quickly fell under siege, with the Ossetian militias engaging the Georgian army. By the end of the day, however, Russia responded in defence of South Ossetia by commencing airstrikes on Gori, the capital of Georgia, and other military targets. ${ }^{4}$ Russian warships were sent to the Black Sea, where at least one Georgian ship was sunk. Russian soldiers were also sent into Georgia with tanks, transport vehicles and heavy weaponry. ${ }^{5}$ The Russian army, with its superior military power, wasted no time in forcing a retreat of the Georgian army out of South Ossetia and in turn moving into other areas of Georgian territory. The basis of the defence by Russia was the fact that many South Ossetians carried Russian passports and thus were regarded as de facto citizens by Russia, and that Georgia had carried out acts of genocide and ethnic cleansing against South Ossetians. ${ }^{6}$ Also in its initial strike on 8 August, Georgia had killed some Russian soldiers stationed around the boarder of South Ossetia; thus Russia claimed to have been acting in defence of its nationals or citizens when it attacked Georgia. ${ }^{7}$ The Russian army, acting in purported self-defence, engaged with the Georgian army in an intensive battle which lasted for about five days. Eventually, they were able to force a retreat of Georgian army out of South Ossetia, and then followed on into other parts of Georgian territory, as Russian army presence was felt in the Georgian cities of Gori and Poti amongst others. ${ }^{8}$

In order to get a proper understanding of what transpired and commenced on 8 August 2008, the relationship between Georgia and Russia must be understood in context. South Ossetia became an autonomous province in the Georgia Soviet Republic at the beginning of 1922, along with Abkhazia. ${ }^{9}$ This was as a result of the annexation of Georgia by the Soviets, who created autonomous regions in Georgia for minority groups like South

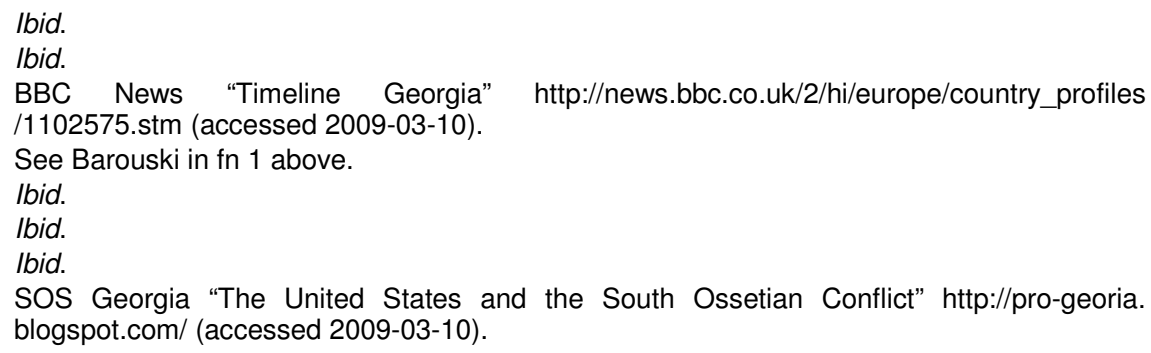


Ossetians and Abkhazians. ${ }^{10}$ In 1936, this autonomy was confirmed by the Soviet Union Constitution, in the newly formed Soviet Socialist Republic (later known as the Soviet Union). South Ossetia however remained known as a region within Georgia. The South Ossetian regional council, in 1989 attempted to get full independence from Georgia. This was in a bid to gain international recognition as a fully independent state. Unfortunately these efforts were met with refusal by the Georgia Supreme Soviet (the governing council of Georgia). South Ossetia then declared itself a Soviet Democratic Republic within the then Soviet Union and even held elections. ${ }^{11}$ This declaration was revoked by the Georgian government in 1990, due to the fact that the Georgia Supreme Soviet had not granted its approval of this action. $^{12}$

When Georgia became independent in 1991, South Ossetia did not receive any diplomatic or international recognition, and as a result maintained its de facto independent status till date. ${ }^{13}$ South Ossetia and Abkhazia carry on as autonomous enclaves, and continue to fight for recognition as independent states. This state of affairs has given rise to continued tensions and intermittent conflicts breaking out between Georgia and these two regions, and is the genesis of the events that occurred in August 2008.

\section{Israel and Gaza}

On 27 December 2008 Israeli forces began a military ground offensive in Gaza. Israel stated that its aim in this offensive was to effectively stop or reduce the capacity of Hamas (the largest and most influential Palestinian militant movement) to continue with the firing and launching of rockets into southern Israel from the Gaza strip, which is one of the territories occupied by the people of Palestine. ${ }^{14}$ Hamas is the largest and one of the most influential Palestinian militant movements. It is an offshoot of the Muslim Brotherhood, a religious and political organization founded in Egypt, with branches all over the Arab world. ${ }^{15}$ It is heavily involved in social work within the Palestinian regions, but it also operates a terrorist wing, carrying out suicide bombings, attacks using mortar and short-range rockets. ${ }^{16}$ Hamas

10 Borgen "International Law, Power Politics, and Russian Intervention in Georgia" http://opiniojuris.org/2008/08/09/international-law-power-politics-and-russian-intervention-ingeorgia/ (accessed 2009-12-24).

11 "Situation around Abkhazia and South Ossetia" http://www.un.int/russia/new/MainRoot/ docs/warfare/statement051208en.htm (accessed 2009-03-11).

12 See Borgen in fn 10 above.

$13 \mathrm{Ibid}$; and de facto independence in the sense that its declaration of independence had not been recognized by either Georgia or any other member of the international community.

14 Statement made by Israel's ambassador to the UN, Ambassador Shalev "Debate on the Situation in the Middle East" http://israel-un.mfa.gov.il/statements-at-the-united-nations/ security-council/sitme311208 (accessed 2008-12-31).

15 "Hamas?" Council of Foreign Relations website http://www.cfr.org/publication/8968/ (accessed 2009-07-09).

16 Ibid. 
has historically refused to recognize the State of Israel, and continued with this refusal since its parliamentary election victory in January 2006. This victory led to crippling economic conditions as Israel tightened its blockade imposed on the Gaza strip. ${ }^{17}$

The genesis of the military offensive on 27 December 2008 can be traced back to the perennial conflict(s) that has/have existed between Israel and the Palestinian Authority over the "occupied" territories on which Palestinians live, and over which Israel exercises a great deal of control. ${ }^{18}$ These territories include the Gaza strip, West Bank and the Golan Heights. As with the case of Russia and Georgia, it is an age-old conflict that has been ongoing for years, and has spread through the Middle East. ${ }^{19}$ Gaza had previously been under Egyptian authority until 1967, when it was captured by Israel. Israel then exercised effective control over the territory of Gaza, until 2005, when it unilaterally withdrew and disengaged from Gaza, after mounting pressure for autonomous rule for the Palestinian people. ${ }^{20}$ According to Israel, its withdrawal was intended to provide an opportunity for the Palestinian people to govern themselves through the Palestinian Authority. At the January 2006 elections, Hamas won 76 out of the available 132 seats, and thus became the "legitimate" government in power. ${ }^{21}$ Thereafter the spate of the daily rocket launches into Israel from Hamascontrolled areas of the Gaza strip increased significantly, leading to a high number of casualties amongst Israeli civilians, and substantial destruction of its infrastructure..$^{22}$ Various international efforts have been made to call a truce and find solutions to the problem, all of which have seemingly failed.

The Israeli defence forces, reportedly in a bid to put a stop to the continuous bombing of southern Israel by Hamas, entered Gaza with their arms and artillery, and began a ground offensive against the Hamas militants. The purpose of this move according to Israel was to substantially destroy the ability of Hamas to continue the firing of rockets into Israel, and consequently to put an end to the firing of rockets into Israel, thus protecting its citizens from the onslaught of Hamas. ${ }^{23}$ The firing of rockets into Israel had been occurring for years, but increased drastically in the last six weeks to the Israeli invasion, and had resulted in many human casualties. Israel stated that it was exercising its inherent right to self-defence as provided in article 51 of the UN charter, as it viewed the rocket and mortar attacks as a terrorist threat. ${ }^{24}$ The ground offensive quickly turned into an "all out" invasion of Gaza as helicopters and tanks were used to quell any resistance 
from the Hamas-led government or the Palestinian people. ${ }^{25}$ This resulted in a humanitarian crisis in Gaza, as many were injured and dead also, with rough estimates putting the death toll at about 900 civilians and more. ${ }^{26}$ Israel imposed a blockage on Gaza during this period; thus not enough food, water and basic amenities were available to the people while the battle continued. The international agencies like the Red Cross and Doctors without Borders also initially found it very difficult to gain access to the people in need. ${ }^{27}$

In the two cases alluded to above, there was full bombardment of the subject countries and or regions by another "sovereign" state. This went against the provisions of international law regarding the use of force. The purpose of this article is to look at the legality of these actions in the light of article 2(4) of the UN Charter, and other international law provisions relating to the prohibition on the use of force and its exceptions.

\section{LEGAL BACKGROUND TO PROHIBITION ON USE OF FORCE}

The prohibition of the use of force by and amongst nations is widely agreed to be a rule of customary international law that has existed and guided the law of nations prior to the formation of the United Nations (UN). Before the world wars there was the general notion of "just" war. The rationale behind this was that a nation was justified if it went to war against another nation, to avenge injuries or wrongs committed against it by the citizens of the other nation, or to restore what has been unjustly taken by the other nation. ${ }^{28}$ This gave rise to a situation where nations were allowed to interpret the basis on which they went to war subjectively, and they were very arbitrary in doing so. They began to extend the definition to suit their vital interests and for propaganda purposes. ${ }^{29} \mathrm{~A}$ number of attempts were made to restrict the use of force but to very limited effect. It took the unprecedented suffering of the First World War to cause a change in the attitudes of nations towards war, and to enable a move towards a total prohibition of use of force. ${ }^{30}$ The 1919 Covenant of the League of Nations laid down a partial prohibition on the resort to war, by requiring members of the League first to submit the matter

25 Klein "The Gaza Air Strikes: Why Israel Attacked" http://www.time.com/time/world/article/ 0,8599,1868829,00.html (accessed 2009-04-06).

26 "Gaza Death Toll" Reuters website http://www.reuters.com/article/newsOne/idUSTRE5053 R720090112 (accessed 2009-07-02).

27 "Gaza Humanitarian Crisis" Oxfam-Quebec website http://oxfam.qc.ca/en/press-releases/ 2009-01-24_gaza-crisis (accessed 2009-03-21).

28 See generally Brownlie International Law and the Use of Force by States (1963) 3-50; and Russell The Just War in the Middle Ages (1975).

29 Malanczuk Akehurst's Modern Introduction to International Law (1997) 308.

30 The second Hague convention of 1907, which prohibited the use of force to recover contract debts, unless there has been a refusal to go to arbitration, the third Hague convention of 1907 , which required war to be preceded by formal declaration of war or by an ultimatum. 
for arbitration by the council, and then to wait three months after the arbitral award before resorting to the use of force. ${ }^{31}$

This partial prohibition was later made total by the General Treaty for the Renunciation of War ${ }^{32}$ which was signed in 1928 by almost all the states in the world. The treaty provided that, "The High Contracting Parties solemnly declare .... that they condemn recourse to war for the solution of international controversies, and renounce it as an instrument of national policy in their relations with one another". ${ }^{33}$ Reservations relating to the right of self-defence were made by the main contracting powers to this treaty, and these reservations were accepted and observed in the regime which emerged from the treaty. According to Brownlie the General Treaty thus forms the background to the formation of customary law in the period prior to the appearance of the UN Charter, and is the legal regime which was the precursor to the Charter. ${ }^{34}$ The International Court of Justice (ICJ) upheld this in finding in its 1968 case that the prohibition on the use of force had become a rule of customary international law that is binding on states that are not party to the UN charter. ${ }^{35}$

\section{Current legal regime}

The essentials of the legal regime above have been incorporated in the UN Charter which now provides a universally accepted legal basis for the use of force as seen in article 2(4) of the UN Charter. ${ }^{36}$ Article 2(4) of the UN Charter prohibits the use of force amongst member states of the UN, except in accordance with the purposes of the UN. It says, "all members shall refrain in their international relations from the threat or use of force against the territorial integrity or political independence of any state, or in any other manner inconsistent with the purposes of the UN". ${ }^{37}$ This effectively imposes a prohibition on the use of force amongst member states. As it is with customary international law, a norm of customary international law can only be changed by another norm of equal weight and equal acceptance by the international community. To this effect article 2(4) is regarded as a prohibition that cannot be altered without universal agreement. ${ }^{38}$ However, it is necessary to note that the rules of the Charter on the use of force are brief and cannot and do not constitute a comprehensive code, especially in view of the changes seen in the nature and type of conflicts in the world today. ${ }^{39}$

31 Article 12 of the Covenant of the League of Nations, http://www.unhcr.org/refworld/ publisher,LON,,,3dd8b9854,0.html (accessed 2009-08-22).

32 Otherwise known as the Kellogg-Briand Pact or the Pact of Paris.

33 Brownlie Principles of Public International Law (2008) 730.

34 Brownlie (2008) 730.

35 Read judgment of the ICJ in Military and Paramilitary Activities In and Against Nicaragua (Nicaragua v US) 1986 ICJ Rep 14.

36 Gray International Law and the Use of Force (2004) 35.

37 Article 2(4) of UN Charter.

38 See the Legality of the Use of Force Case (Yugoslavia v US) 1999 ICJ Reports.

39 Gray 6. 
Customary international law rules in relation to the use of force are also of great legal importance. The ICJ in the Nicaragua case apparently regarded the Charter provisions as dynamic rather than fixed, and thus as capable of change over time through state practice. ${ }^{40}$

The Charter contains certain exceptions to the general rule on the prohibition of the use of force contained in Article 2(4). The first is that force can be used when it is sanctioned by the UN Security Council. ${ }^{41}$ The UN Charter lays the primary responsibility for the maintenance of international peace and security with the Security Council, acting on behalf of the UN General Assembly, ${ }^{42}$ whilst article 53 of the charter provides for the need for Security Council authorization of enforcement action by regional organizations. The UNSC is authorized to take decisions that are binding on member states, ${ }^{43}$ and as such must act on behalf of member states with respect to threats to the peace, breaches of the peace and acts of aggression with the aim of maintaining or restoring international peace and security. ${ }^{44}$ The initial action of the UNSC must be by way of non-military measures taken to restore international peace and security. If such measures fail, the charter provides for action by land, air or sea forces as may be necessary to maintain or restore international peace and security. ${ }^{45}$ In reading all these other articles together with article 2(4) of the charter, one sees that the rule of international law as laid down by the charter is that the use of force is prohibited unless authorized by the Security Council. ${ }^{46}$

Another exception to the prohibition on the use of force is the right of selfdefence. Article 51 of the Charter provides for the inherent right of individual or collective "use of force" in self-defence in the case of an armed attack against a member of the UN. This individual or collective use of force is permitted to continue until such a time as the Security Council takes such actions as are necessary for the maintenance of international peace and security (emphasis mine). ${ }^{47}$ This article has been subject to varying interpretations, as it does not stipulate the extent to which a "nation" or "collective" can use force in "self-defence", nor what action(s) would qualify for an armed attack in self-defence. ${ }^{48}$ The phrase "armed attack", it has been argued, cannot mean the presence of an armed attack, but should rather include a situation where an armed attack is anticipated (for example,

40 Military and Paramilitary Activities In and Against Nicaragua (Nicaragua v US) supra par 176.

41 Hereinafter "UNSC".

42 Article 24 of UN charter.

43 Article 25 of UN Charter.

44 Article 40 and 41 of UN Charter.

45 Article 42 of UN Charter.

46 Stemmet "International Law and the Use of Force: Some Post 9/11 Perspectives" 2003 148(5) The Rusi Journal 25.

47 Article 51 of the UN Charter.

48 See generally Travalio "Terrorism, International Law and use of Military Force" 2000 Vol 18 Wisconsin International Law Journal 145; Schachter "The Lawful Use of Force by a State Against Terrorists in Another country" in Han (ed) Terrorism and Political Violence: Limits and Possibilities of Legal Control (1993) 243-266. 
anticipatory self-defence). Certain states have interpreted article 51 in these terms, and have taken military action to prevent such armed attack, ${ }^{49}$ and have resorted to the justification of self-defence in the case of their actions being queried. ${ }^{50}$ An example of this is the 1993 missile attack on Iraq by the US, in purported self-defence and anticipatory self-defence. In the 1993 missile attack, the legal justification given to the UNSC by the US on the day of the attack was the fact that there had been a foiled assassination plot, sponsored by the government of Iraq, to kill the then president of the US, George Bush, during his visit to the Kuwait in April $1993{ }^{51}$

Apart from the two exceptions to the prohibition on use of force provided for in the charter, there are also some situations that have evolved over time, which may count as exceptions under customary international law, but over which there are still much uncertainty and controversy relating to the legality of such exceptions. ${ }^{52}$ The use of the phrase "inherent right" in article 51 of the UN Charter gives the connotation of something that has existed prior to, or that dates back before the time. These have been said to include instances where it is permissible to use force under customary international law. Use of force in defence of nationals and humanitarian intervention are instances developed by customary international law, when it is said to be permissible to use force. ${ }^{53}$

Humanitarian intervention is not provided for in the UN Charter, and is not a legal right in international law. There, however, exists a substantial body of opinion that when a state commits acts of cruelty against and persecutes its own nationals in such a way as to deny their fundamental human rights and to shock the conscience of mankind, use of force, in the form of intervention in the interests of the people might become legally permissible. ${ }^{54} \mathrm{An}$ example of this is NATO's 1999 armed action in Yugoslavia, which though it was justified in terms of humanitarian intervention, but did not meet with unanimous approval; also the US action in Iraq in 2003. This concept of the protection of citizens from such acts of cruelty continues to gain a lot of prominence internationally. The former Secretary General of the UN, Mr Kofi Anan, in his report at the fifty-ninth session of the General Assembly, noted, "the principle of non-intervention in internal affairs cannot be used to protect genocidal acts or other atrocities, such as large-scale violations of international humanitarian law or large-scale ethnic cleansing, which can

49 Israel's 1981 attack on Iraqi nuclear installation at Osiraq in Iraq was purportedly undertaken in self-defence. Israel undertook these attacks on Osiraq, the site of the construction of a nuclear reactor in Iraq on the justification that the nuclear programme had the potential to produce nuclear weapons for Iraq that would be used against Israel.

50 Rothwell "Anticipatory Self-defence in the Age of international Terrorism" 2005 University of Queensland Law Journal 27.

51 Kritsiotis "The Legality of the 1993 US Missile Strike on Iraq and the Right of Self-Defence in International Law" 199645 International Comparative Law Quarterly 163.

52 Brownlie (1963) 3-50 and 257-258.

53 See generally Gray 31-37 and 128-129.

54 Barrie "Forcible Intervention and International Law" 19994 SALJ 800; and see also UN High Level Panel report on "Threats, Challenges and Change" UNGA Doc A/59/565. 
properly be considered a threat to international security and as such provoke action by the SC". 55

The concept of use of force in defence of nationals has evolved over time, though not contained in the UN charter. It has been used by states to justify interventions where nationals are in immediate danger of losing their lives or are threatened with serious injury. ${ }^{56}$ It was used by the US to justify its armed interventions in Latin American states like Grenada in 1983, Panama in 1989, and most currently by Russia in its August 2008 attack on Georgia. This defence has not met with international recognition or international acceptance as its interpretation is very subjective. Also the weight and value to be attached to the "danger" or "serious injury" that nationals would face for it to merit use of force are not definite and depend on different situations and which states are involved. ${ }^{57}$ It is regarded by some as an aspect of the customary-law right of self-defence ${ }^{58}$ In order to understand the customarylaw exception better, one would need to take a brief look at the genesis of this concept. The customary international-law concept of self-defence was first enunciated in the Caroline case.

\section{The Caroline case}

The Caroline incident happened in $1837,{ }^{59}$ when British soldiers violently seized the steamboat SS Caroline, which they alleged was being used by American rebels for armed raids on Canadian territory, and sometimes on British ships sailing the area. The ship was later set on fire and sent over the Niagara Falls. This incident resulted in the death of two US nationals. Correspondence then ensued between the British and American governments as to the legitimacy of the British action and a demand for redress by the American government. ${ }^{60}$ It was in the course of this correspondence that principles governing the customary-law right to selfdefence in the law of Nations were enunciated. The then US Secretary of State, Daniel Webster, asserted that Britain would need to show a "necessity of self-defence, instant, overwhelming, leaving no choice of means, and no moment for deliberation. It will also be for it to show that the local authorities of Canada, even supposing the necessity of the moment ... did nothing unreasonable or excessive, since the act justified by the necessity of selfdefence must be limited by that necessity and kept clearly within it" ${ }^{61}$ This was the first statement of the now well-formed principles of "necessity" and

55 "A More Secure World: Our Shared Responsibility" report of the UN High Level Panel report on Threats, Challenges and Change. UNGA Doc A/59/565 (a panel set up by the former Secretary General of the UN, Mr Kofi Anan). Barrie 19994 SALJ 803.

Ibid.

58 See Bowett Self-defence in International Law (1958) 87-105; and Cassese The Current Legal Regulation of the Use of Force (1986) 39-55.

59 Rothwell 2005 University of Queensland Law Journal 25.

60 lbid.

61 Jennings "The Caroline and Mcleod Cases" 193832 American Journal of International Law 89. 
"proportionality" in instances of action taken by a state in self-defence on another state. The principle of necessity speaks to the fact that there must be clear and tangible evidence that an attack was pending or imminent. That means that the state acting in self-defence must have real evidence of an impending or imminent attack directed at it by the other state. The principle of proportionality on the other hand requires that the degree of force used in self-defence must be commensurate with the ends to be achieved, such that every self-defence measure should be quantified by the scale of the unlawful act which provoked it. This is because excessive force would jeopardize the legality of any operation undertaken in self-defence. ${ }^{62}$

In the situations of the use of force in self-defence enumerated above, there exist uncertainties as to the measure of the requirements of necessity and proportionality. There are no fixed ways in international law of judging how necessary or proportional the force must be. These principles of necessity and proportionality have been put to the test before the ICJ in a number of cases, key amongst which is the Nicaragua case. ${ }^{63}$ In this case the United States was alleged to have supported (through training, equipping, arming and organizing) the activities of the contra force (a mercenary army), carried out in Nicaragua and against the Nicaraguan people. These activities were said to be inimical to the stability of Nicaragua. The ICJ in giving its decision reaffirmed the inherent right of self-defence and the conditions of necessity and proportionality that have to be satisfied for the defence to be tenable. ${ }^{64}$ The court did not really examine these limitations of necessity and proportionality in the Nicaragua case, because the court had already found that the US use of force was illegal, and thus the criteria of necessity and proportionality were said by the court to be additional ground of wrongfulness. ${ }^{65}$

In state practice it is to be noted that the factors of necessity and proportionality are often the only factors relied on in deciding the legality of particular actions. They constitute a minimum test by which to determine that a use of force does constitute self-defence ${ }^{66}$ The factors of necessity and proportionality also help states in distinguishing unlawful reprisals from lawful self-defence. ${ }^{67}$

These factors of necessity and proportionality have also been incorporated as part of the five basic criteria of legitimacy that have been suggested for the UNSC in the High Level Panel report, in deciding whether or not to authorize or endorse the use of military force. ${ }^{68}$ In the report the issue of necessity addresses the need for the use of force in self-defence

62 Kritsiotis 199645 International Comparative Law Quarterly 170.

63 Military and Paramilitary Activities case (supra); other cases include the Advisory Opinion on the Legality of the Threat or Use of Nuclear Weapons 1966 ICJ Reports 226; and the more recent Oil Platforms case 2003 ICJ Reports par 43.

64 Ibid.

65 Gray 122

66 Ibid.

67 Ibid.

68 UN High Level Panel report (supra). 
that is, the seriousness of the threat, while the issue of proportionality is captured under "proportional means" and means the minimum degree, intensity, duration of force that should be used in self-defence should be such as is necessary to meet the threat in question. ${ }^{69}$

\section{APPLICATION OF THE LEGAL PROVISIONS TO THE CONFLICTS}

As stated above, the aim of this paper is to examine the two conflicts discussed in the first part of this article, the justifications adduced for the use of force in these cases in the light of the international law rule on the use of force and its exception of self-defence. This article would not go into the different political history and reasons that have been suggested for the conflicts, especially in the case of Russia, ${ }^{70}$ nor would it attempt to address these issues. Such an attempt would require another full article. As with the Israel/Palestine conflict, the Russia/Georgia conflict is part of a much bigger confrontation that plays extremely well in the domestic politics of the countries involved, that is tied to intractable bilateral issues, and for which we have seen mobilization on the part of the different sides economically, politically and militarily. ${ }^{71}$ The focus here will be on the actions taken by the states in the conflicts and the international law implications of the actions. Each state's justifications will be examined closely in order to determine the legality of the use of force in these instances.

In the case of the August 2008 conflict between Georgia and Russia, Georgia invoked the principle of state sovereignty to the effect that since South Ossetia's bid to secede had not received any formal diplomatic recognition from any other sovereign state (not even Russia) or international organization, it therefore remained part of the Georgian state, and as such the state had the right to deal with cases of separatist militias that sought to threaten the peace and sovereignty of the Georgian state. ${ }^{72}$ This is in support with international law, which treats secessionist conflicts as matters of domestic law, to be dealt with by the state in question. ${ }^{73}$ Georgia further viewed Russia's intervention on behalf of South Ossetia (its unauthorized entry into Georgian territory), and its attack on Georgian forces as an act of

\footnotetext{
Ibid.

70 It has been suggested that Russia had ulterior motives for going to war with Georgia, some of which would be the desire to return to the super-power status it had during the USSR era; the use of force could also be construed as posturing by Russia and sending a message to the West that it was still to be reckoned with, and finally Russia's opposition to Georgia joining NATO because that would mean a potentially unfriendly military presence on Russia's border, and also because Russia seeks to maintain its sphere of influence, and Georgia being accorded NATO membership would not only encroach on this influence, but would also mean that Western European influence would be within its territory.

71 Sestanovich "Russia-Georgia Spat: Part of a Much Bigger Confrontation" website of the Council on Foreign Relations http://www.cfr.org/publication/11602/sestanovich.html (accessed 2009-07-02).

72 See Barouski in fn 1 above.

73 See Borgen in $\mathrm{fn} 10$ above.
} 
aggression as defined in the UN General Assembly Resolution 3314 of $1974,{ }^{74}$ and a violation of Article 2(4) of the UN charter. The Russian defence and justification was to the effect that they were coming to the aid of Russian citizens (South Ossetians carrying Russian passports, and the Russian peacekeepers who had been stationed in South Ossetia). Thus Russia invoked the right of self-defence to defend its citizens, citing article 51 of the UN charter which allowed the use of force for self-defence from an armed attack until the SC undertook measures against the aggression. ${ }^{75}$

These justifications offered by both Georgia and Russia are all grounded in international law. What goes to issue is the weight to be attached to each of the defences and justifications given. Article 2(4) and its exceptions in the UN charter (where the use of force is ordered or sanctioned by the UN itself, ${ }^{76}$ and where force is used in self-defence), ${ }^{77}$ have been discussed above. In international law these exceptions are the only widely recognized cases where a state would not be in violation of international law in its use of force. For example, the US-led attack on Afghanistan after the 9/11 terrorist attacks was not viewed as being in violation of international law, and in fact had the backing of the international community as a whole due to the fact of the preceding attacks on the US. It would be negating basic international law rule if states were allowed to go beyond the provision and to interpret the charter to suit themselves.

The argument of Georgia in this case would appear to be very germane. In cases of self-determination, a region (even if semi-autonomous) is only viewed as a sovereign state if it is able to exercise all the rights and responsibilities of a state, only after is it accorded recognition (either expressly or tacitly) by the international community of sovereign states. ${ }^{78}$ This is not the case with South Ossetia, and thus in international law, Georgia still has the right to exercise the rights and responsibilities of a state over South Ossetia. This includes the right to control and stop activities of secessionists within its territory.

In dealing with Russia's defence of protecting its citizens, it is submitted that for any of the exceptions to article 2(4) of the UN Charter to be exercised validly, there must be notification and even authorization by the UNSC, even if after the fact as in the case of article 51. This applies both to the treaty exceptions and the customary international law exceptions. In the case of the treaty exceptions, articles 41 and 42 are actions been taken by the UNSC itself and thus already involve UNSC notification. Article 51, whilst granting the right of individual and or collective self-defence, foresees a situation where the UNSC is immediately informed of the use of force in

74 Resolution 3314 of 1974 defines aggression as "the use of armed force by a state against the sovereignty, territorial integrity or political independence of another State, or in any other manner, inconsistent with the Charter of the UN ..."

75 See Barouski in fn 1 above.

76 Articles 41 and 42.

77 Article 51.

78 See generally Chapter 3 of Raic Statehood and the Law of Self-determination (Developments in International Law Series) (2002). 
order for it to take actions necessary for the maintenance of international peace and security. However, in the situation of the customary-law exceptions, it is submitted that the authorization of the UNSC would be necessary before such military action can be taken. ${ }^{79}$ This is necessary to prevent the re-enacting of the pre-1945 situation, where nations used whatever justifications they felt were necessary to satisfy the "just war"requirement for engaging in armed conflict with another nation. It is interesting to note that Russia also made reference to the just-war principle, upon which the "Responsibility to Protect" doctrine is based. ${ }^{80}$ Russia in adducing self-defence, is asserting that it is exercising its responsibility to protect its citizens in South Ossetia.

\section{The responsibility to protect}

Responsibility to protect as an emerging norm in international law is encapsulated in the report of the UN High Level Panel. ${ }^{82}$ The report dealt with the realities of the horrors of successive humanitarian disasters over the years in places like Bosnia Herzegovina, Kosovo, Rwanda and even now Darfur in Sudan, and noted the growing acceptance amongst states to have the primary responsibility to protect their own citizens. ${ }^{83}$ It went further to state that when sovereign states are unwilling or unable to so protect, then the responsibility should be taken up by the wider international community as a collective. Thus the now accepted doctrine of "responsibility to protect" is one exercisable by the UNSC, authorizing military intervention as a last resort in the face of genocide and other large scale killings, or serious violations of international humanitarian law, when the sovereign state in whose territory the breaches are happening, has proved powerless or unwilling to prevent it. ${ }^{84}$ The military intervention would, however, need to satisfy certain criteria for legitimacy upon which the doctrine of responsibility to protect is hinged.

The doctrine, though allowing cases of use of force in a "non treaty"- or "customary law"-situation, also lays down strict rules and conditions for the exercise of the doctrine. The pre-conditions to the exercise of the responsibility to protect are as stated above: cases of genocide, serious violations of international humanitarian law, etcetera. These must exist before force can be used to stop the violations. Also it must be apparent that the state (within whose borders it is happening) is unwilling or unable to stop the activities, and then, lastly, the use of force must be a decision of Security Council. Also the manner in which force is used is regulated by the criteria for legitimacy as contained in the UN report (seriousness of the threat, last resort, right intention, proportional means, and reasonable prospects of

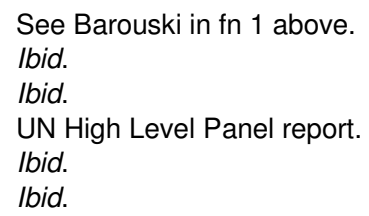


success). Russia's assertion that Georgia was engaged in ethnic cleansing, genocide and other war crimes should first have been tested before the UNSC. The decision to intervene in South Ossetia, using armed force, should have been taken by the collective international community, represented by the UNSC, and lastly, the force used should have been proportional. In this case, the force used was disproportionate because Russia went beyond South Ossetia to invade and attack other regions of Georgia proper up to Gori, the capital of Georgia. ${ }^{85}$ It is therefore contended here that Russia's claim to have been protecting its citizens under international law is without any legal backing or legitimacy in international law.

Looking at the case of Israel's attack on Gaza, the facts of which have also been documented in the first part of this article, the attack launched on Gaza by Israel on 27 December 2008 was stated as being an act to put a stop to the continuous barrage of rockets into its southern part from Hamas militants based in Gaza. ${ }^{86}$ The rocket launches had been ongoing for a number of years, despite diplomatic efforts to stop them. Israel had imposed strict control measures on Gaza, and even closed its borders with Gaza on occasions in a bid to monitor the supply of weapons to Hamas. ${ }^{87}$ All of this had failed to stop or even reduce the spate at which rockets and other weapons were being launched into Israel.

In order to determine if Israel's actions were legal, one would need to establish if Israel met with the requirements relating to the invocation of article 51 of the UN Charter. Article 51 is conditioned on an armed attack having occurred. The question is then: Was there an armed attack in this case? To answer this question, one would need to look at the facts and the nature of the rocket launches into Israel to see if they could constitute an armed attack. Hamas rockets have been continuously launched from Gaza into southern Israel for the past couple of years. This is a fact to which there is no dispute. At times they are launched in their multiples every day. ${ }^{88}$ These rockets are indiscriminate, with no radar for control and so most times they hit different targets, destroying houses, maiming or killing people. Hamas claimed that its rocket launches were due to the fact that Israel maintained a blockade over Hamas. ${ }^{89}$ Israel's blockage on Gaza involved controlling of the borders and determining who and what would go in or come out. ${ }^{90}$ The situation had persisted in the full glare of the international community and efforts to intervene, deliberate, or to stop the rocket launches

35 See Barouski in fn 1 above; and see Borgen in fn 10 above.

86 Statement of Israel's UN ambassador to the UN, supra.

87 See Robin in fn 18 above.

88 Global Security "Hamas Rockets" http://www.globalsecurity.org/military/world/para/hamasqassam.htm (accessed 2009-07-01).

89 Human Rights Watch report titled "Israeli Blockade Unlawful despite Gaza Border Breach" http://www.hrw.org/en/news/2008/01/25/israelgaza-israeli-blockade-unlawful-despite-gazaborder-breach (accessed 2009-07-01).

90 Ibid. 
had failed to date. ${ }^{91}$ It is doubtful if any sovereign nation would allow rockets to be flown into its territory for years killing its people and in continuous violation of international law without taking action. This brings into operation the international customary-law provisions of "necessity" and "proportionality" for the invocation of self-defence. These requirements also form part of the requirements for legitimacy of action as indicated in the UN High Level panel report above. In applying "necessity", the question to be asked would be "were the attacks from which Israel was defending herself of such a nature that Israel had no choice but to take the steps it took in using force on Gaza?" It would appear that Israel was left with no choice of means in this situation, but to invoke article 51 for use.

One of the problems encountered in applying international law to this situation is that of the status of Palestine in International law and consequently the way to treat the rocket attacks from Hamas. The fact of the matter is that Palestine is not recognized as a state in the international community. Although, since 1974 Palestine (formerly known as the Palestinian Liberation Organization (PLO)) had an observer status in the UN. ${ }^{92}$ It was later in 1988 designated as plainly "Palestine" within the UN. The UN later granted Palestine a super observer status in the UN. ${ }^{93}$ The ICJ in its advisory opinion on the wall constructed by Israel, ${ }^{94}$ accorded Palestine full rights of a state by granting it the right to participate in proceedings before it in this matter. Though contrary to the provisions of the ICJ statute, the court accorded procedural recognition to Palestine for the purposes of the matter before it. ${ }^{95}$

Following the strict interpretation of article 51 of the UN Charter, it would seem that a right of self-defence can only be exercised against another state and not against groupings of people or non-state actors. ${ }^{96}$ This position may have changed considerably after the September 11, 2001 attacks on the US. The post-September 11 era has forced a re-evaluation of the notion that only a state can mount an armed attack on another state in the light of acts of international terrorism, mostly emanating from non-state actors operating within a state. Non-state actors are now recognized as also being very capable of carrying out armed attacks, and the provisions of article 51 must be construed in this sense, especially if there is connivance of the state in

91 Initiatives and efforts made by the international community, including the fellow Arab states and the US.

92 Caplen "Rules of 'Disengagement': Relating the Establishment of Palestinian Gaza to Israel's Right to Exercise Self-Defence as Interpreted by the ICJ at the Hague" 200618 Florida Journal of International Law 679.

93 According to the General Assembly resolution 250 "super observer status includes the right to participate in debate and co-sponsor draft resolutions provided that such draft resolutions and decisions ... be put to vote only upon request from one Member State".

94 Advisory Opinion of the ICJ on the "Legal Consequences of the Construction of a Wall in the Occupied Palestinian Territory" 2003 ICJ Reports.

95 Ibid.

96 "ICJ decision in the Legal Consequences of the Construction of a Wall in the Occupied Palestinian Territory Case" 200443 International Legal Matters 10091072 (separate opinion of Judge Kooijmans). 
which the non-state actors operate from. ${ }^{97}$ This position is recognized by Brownlie when he says, "a co-ordinated and general campaign by powerful bands of irregulars, with obvious or easily proven complicity of the government of a state from which they operate, would constitute an armed attack, more especially if the object were the forcible settlement of a dispute or the acquisition of territory". ${ }^{98}$ The fact that Hamas is in government in Gaza means that the attacks can be regarded as "government condoned" and "government sponsored", even though the attacks are carried out by the military wing of the same organization. Therefore Israel would be deemed to have a legal basis to exercise its individual right to self-defence in the face of the rocket attacks.

\section{EXERCISING THE RIGHT OF SELF-DEFENCE}

There has been a lot of international condemnation of Israel's use of force in the Gaza strip, from the member states of the UN, to international organizations (like the ICRC, Human Rights Watch), to academics also. Conor Gearty, ${ }^{99}$ the director of the Centre for the Study of Human Rights at the London School of Economics, is of the opinion that, though it may be stated that Israel had a right to self-defence under international law, the manner in which such right was exercised leaves a lot to be desired. International humanitarian law (IHL) provides conditions for engaging in hostilities, and stipulates the standard at which such hostilities are to be conducted. It requires all parties to a conflict to observe certain trite norms during the conflict. ${ }^{100}$ Israel, in its use of force, does not appear to have distinguished between combatants and civilians, neither is it clear that it targeted only the combatants (in this case Hamas militia); access to and the provision of medical treatment for the sick and wounded by the party within whose power it is to do so (Israel in this case), or allowing of access to international organizations who are capable of such treatment like the ICRC, was very limited. This is judging from the reports of various international agencies that were operational within the region. The body of laws known as the Geneva Conventions provides for the discriminate use of weapons of warfare, but also the prohibition of the use of those weapons which are likely to cause unnecessary loses or excessive suffering. These provisions of the Geneva Convention seem not to have been honoured. ${ }^{101}$ All of these are provisions under international humanitarian law for combat situations.

97 See SC resolutions 1368 and 1373 of 2001; and also see Caplen 200618 Florida Journal of International Law 679, particularly section IV of the article, where he discussed the status of Palestine in the UN, and the ICJ decision in its 2004 advisory opinion on the legal consequences case.

98 Brownlie (1963) 278-279 and 361.

99 "Israel, Gaza and International" Open Democracy News Analysis http://www.democracy.net. forward.47186 (accessed 209-02-24).

100 Protocols I and II to the 1949 Geneva Convention on Humanitarian International Law.

101 Phosphorous weapons - ICRC's view: www.icrc.org/Web/Eng/siteeng0.nsf/html/weaponsinterview-170109 (accessed 2009-02-24). 
It has also come to light that Israel made use of white phosphorous weapons in ways that run counter to the provisions of IHL in Gaza. Israel has confirmed the use of white phosphorous, but claims to have used it in accordance with international law. ${ }^{102}$ Protocol III of the 1980 Convention on Certain Conventional Weapons prohibits the use of white phosphorous weapons within concentrations of civilian populations. Such weapons can only be used if the military objective against which it is directed is clearly separated from civilians. ${ }^{103}$ The convention also prohibits the air-dropping of such incendiary weapons within a concentration of civilians. ${ }^{104}$ It is alleged that Israeli attacks "were directed at civilians or civilian buildings", while others were disproportionate or indiscriminate and that Israel failed to grant access to the wounded and sick to get medical treatment, and that there was a general violation of human rights during the conflict by both parties. These allegations have been investigated by different human rights' bodies and the UN, ${ }^{105}$ and they have been validated. ${ }^{106}$ The separation of military objectives and objects from civilians would have been very difficult to do in Gaza, as congested as it is. There are certain factors which would create this difficulty. Hamas as a militia, not being a uniformed army, its militants could easily pass for civilians as there is nothing to distinguish them from the civilian population. However, the duty for Israel, in seeking to comply with international law and international humanitarian law, was to have found a better way of rooting out Hamas militants at a minimum cost to the civilian population. The report found that there was strong evidence to establish that numerous serious violations of international law, both humanitarian law and human rights law, were committed by Israel during the military operations in Gaza. ${ }^{107}$

The exercise of Russia's right to "self-defence" is found to have been in breach of the principles of international law as stated above. The European Union sponsored an investigation into the conflict, the report of which was released on 30 September $2008 .^{108}$ The report found both parties to have breached international law. In dealing with the Russian claim of a right to self-defence, the report found that the use of force by Russia in self-defence during the initial phase of the conflict was justified as it was protecting its citizens in South Ossetia. ${ }^{109}$ However, when the Russian forces began to

\footnotetext{
Ibid.

Protocol III of the 1980 Geneva Convention on Certain Conventional Weapons.

See Phosphorous weapons - ICRC's view in fn 101 above.

05 The UN Fact-Finding Mission on the Gaza conflict presented its report to the UN Human Rights Council on 29 September 2009.

106 UN enquiry on the targeting and attacking of UN buildings and people taking refuge in UN offices. The statement of the Human Rights Council (HRC) is contained in Gearty's article in 99 above.

107 Ibid.

108 "Report of the Independent International Fact-Finding Mission on Conflict in Georgia" http:// www.consilium.europa.eu/uedocs/cms_data/docs/pressdata/en/er/110370.pdf (accessed 2010-03-15).

109 Iliopoulos "EU Report Targets Both Sides in Russia/Georgia Conflict" http://www.crimesof war.org/onnews/news-georgia2.html (accessed 2010-03-15).
} 
delve deeper into Georgian territory, their actions became disproportionate to the threat posed to its citizens in South Ossetia and to its peacekeepers. Their actions therefore went beyond reasonable defensive agreement and were therefore a violation of international law. ${ }^{110}$

\section{CONCLUSION}

It is necessary that the rules of international law relating to the use of force in self-defence are clear and explicit, not giving room for manoeuvre or justification by states. States have and continue to use and try to use international-law rules to justify their many acts of violation of international law. The body of rules regulating the use of force in international law is quite clear and explicit, but the interpretations of these rules by member states have many times been controversial. Conversely, it is necessary to remember part of the judgment of the ICJ in the Nicaragua case to the effect that the charter provisions on the use of force are dynamic rather than fixed, and as such still capable of change over time through state practice. ${ }^{111}$

The lack of an enforcement mechanism under the UN structure makes it easier for states to continue to violate the rules of international law blatantly, under different pretexts, amongst which is self-defence. The instances of unilateral action taken purportedly in self-defence are continuing to increase with time, and there is a need for the international community to settle the polarization and controversy, in a bid to enforce properly the rules of international law guiding the use of force. This is despite the lack of an international enforcement mechanism, and in view of the recognition of the fact that international law and the UN structure exist to prevent anarchy and a recurrence of the era of world wars with its untold human cost. As stated in the High Level Panel report, "Article 51 needs neither extension nor restriction of its long-understood scope ... the task is not to find alternatives to the Security Council as a source of authority but to make it work better than it has" (author's own emphasis). ${ }^{112}$

10 Ibid.

11 Military and Paramilitary Activities In and Against Nicaragua (Nicaragua v US) supra par 176.

112 See UN High Level Panel report on "Threats, Challenges and Change" UNGA Doc $\mathrm{A} / 59 / 56553$. 